International Journal of Linguistics, Literature and Translation

ISSN: 2617-0299 (Online); ISSN: 2708-0099 (Print)

DOI: 10.32996/ijltt

Journal Homepage: www.al-kindipublisher.com/index.php/ijltt

\title{
Translating Booster Expressions: How the Competence of the Translator is Influential?
}

\author{
Dhesta Maydiana Sari ${ }^{1}$ (D) $\triangle$, M.R. Nababan² 8(D, Riyadi Santoso ${ }^{3}$ (D) \\ ${ }^{1}$ Student of Linguistic Department in Sebelas Maret University, Indonesia \\ ${ }^{23}$ Lecturer of Linguistic Department in Sebelas Maret University, Indonesia
}

$\triangle$ Corresponding Author: Dhesta Maydiana Sari, E-mail: maydiana.dhesta.md@gmail.com

\author{
ARTICLE INFORMATION \\ Received: April 15, 2021 \\ Accepted: May 25, 2021 \\ Volume: 4 \\ Issue: 5 \\ DOI: $10.32996 / i j l l t .2021 .4 .5 .30$
}

\section{KEYWORDS}

Presentation, rhetorical devices, booster expression, translation studies.

\section{ABSTRACT}

This research aims to see how booster expression as rhetorical devices in several presentation transcripts provided TED.com are translated from English into Indonesian. Given that there are cultural differences in the use of booster expressions from the two countries. Therefore, the objectives of this study are threefold. 1. To find out what presenters use booster expressions as rhetoric tools in several presentations at TED.com, 2. Then look at what translators use translation techniques in translating booster expressions from English into Indonesian. This research is descriptive qualitative research. Data were taken from six presentation transcripts at TED.com and transcripts translated into Indonesian. All data will be categorized according to the rhetorical function of the booster expression. Then the researcher will see what translation techniques are used in translating the booster expression. Data validation was carried out through FGD before the analysis was carried out. The study results revealed that not all the booster expressions could be well translated. This can be seen from the considerable number of deletion techniques applied by the translators. Several assumptions became the reason for selecting this technique, specifically; the cultural differences between the source language and the target language in using booster expressions and the lack of translator competence in translating booster expressions.

\section{Introduction}

Presentation is one of the ways to convey opinions in a public space. In general, presentations are delivered by speaking in front of many people about certain topics, opinions, or information. A good presenter will be able to influence the audients and also can even provide good and systematic thought direction through his presentation. In order to achieve the objectives of his presentation, rhetorical devices are often used. A rhetorical device is a linguistic device used by speakers, in this case, the presenters, to convince or persuade their audients about the arguments which are presented. In linguistics, the forms of rhetorical devices can be various, such as language style, expressive expressions, the use of quotations, and one of them is the use of booster expressions.

Booster expression in many studies is often juxtaposed with hedges. Both are included in meta-discourse markers with different functions. If hedges are a tool used to mitigate speech, boosters have another function. Hyland (1998) defines boosters as a communication strategy to increase the strength of a statement and emphasize certainty, strong commitment, belief, and truth. From the definition given by Hyland, it can be said that boosters play an important role in a statement, especially to strengthen arguments and increase persuasiveness in it. This is very necessary for a presenter to convince and even influence listeners so that the objectives of the presentation can be achieved.

Since booster expression is as significant as hedges, booster expression can be an interesting device to be studied in linguistics. Unfortunately, there are still very few studies discussing booster expression when compared to hedges. Previous studies on hedges and boosters discuss the comparison of the use of these two devices in academic discourse. Among these studies, many

\section{K C AL-KINDI CENTER $R$ D FOR RESEARCH AND DEVELOPMENT} Your gateway to world-class research

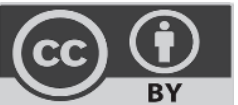

Published by Al-Kindi Center for Research and Development, London, United Kingdom. Copyright (c) the author(s). This open access article is distributed under a Creative Commons Attribution (CC-BY) 4.0 license 
researchers compared the applications of these two devices from one language to another and some compared their applications in English language research articles or journals written by native English speaker students and non-native English speaker students. As a result, there are differences in both the frequency and the types of hedges and boosters applied. This study reveals that the cultural differences influence hedges dan booster expression and their writings reflect it.

The results of this study then become a reference for linking the study of booster expression to translation studies. The existence of cultural differences between the Source Language (SL) and the Target Language (TL) is one of the obstacles in translation. If a translator cannot bridge these cultural differences, it will impact the quality of the translation result. In fact, a good translator is required to be able to transfer the meaning from $S L$ to $T L$ as accurately as possible so that the message of the communication can be well delivered in Target Language. In the translation of English into Indonesian, for example, it is found that the use of booster expression in English is often pronounced more expressively than in Indonesian. The word "sangat bagus" for example, in English, can be expressed in various ways, such as; "very good", "damn good", "so good", "fucking good" and etc.

A translation study regarding booster expressions, especially in English - Indonesian or vice versa, was conducted by llham (2018). This kind of study has never been done before. The study, Ilham (2018), examines the comparability of two versions of English-Indonesian translation of booster expressions found in assertive speech acts. The data of the study are taken from Agatha Christie's novel untitled ABC Murder, which published in 1976 and 2017. As a result, researchers found many differences in the use of translation techniques in the 1976 and 2017 translations.

From the description above, this study aims to examine how translators translate booster expressions as a rhetorical device in presentation from English to Indonesian. On another side, it is found that there are cultural differences in the use of booster expressions in these two languages. The study data are taken from six presentation transcripts and the Indonesian translation provided by TED.com.

\section{Literature Review}

Since this study is focused on booster expression, rhetorical devices, and translation, some related theories are used to obtain the aim of the study. These theories are explained below.

\section{Translation}

Over the years, many researchers have dedicated themselves to developing translation studies. Quoted from several experts, these are the definitions of translation. The first definition is by Catford $(1978$, p. 20). According to him, translation is the replacement of equal textual material from the source language into the target language. However, this definition is considered incomplete since Catford does not mention the context of text or utterance from the source language, which impacts the translation result's quality.

Then, Larson $(1984$, p. 3) adds that translation includes the transfer of meaning from the source language to the target language by paying attention to the semantic structure of the source language and target language and emphasizes that meaning must be transferred properly. The definition of translation is further disclosed by Newmark (1988: 5), which states that translation is the delivery of meaning from one text to another in accordance with the message of the original text author. Next, Nida (1969: 12) states that translating must be a natural equivalent and the closest to the message of the source language, both relating to meaning and language style.

Of the definitions above, several things regarding translation need to be underlined, including; 1 ) translation process is actually a transferring process, 2) the object of the translation will not be separated from the text material, the equivalent of the word, and the meaning or message contained in the text, 3) several important elements must be considered in the translation process, namely; language style, semantic elements, equivalence and meaningfulness of the source language so that the message conveyed can be translated properly.

\section{Translation Techniques}

Molina and Albir (2002: 509) define translation techniques as a way that is applied to analyse and classify how a translation corresponds to the source text. Molina and Albir (2002: 50) divide translation techniques in detail into 18 types of techniques, namely; 1) Adaptation, 2) Amplification, 3) Borrowing, 4) Calque, 5) Compensation, 6) Description, 7) Discursive creation, 8) Established Equivalent, 9) Generalization, 10) Linguistic amplification, 11) Linguistic compression, 12) Literal translation, 13) Modulation, 14) Particularization, 15) Reduction, 16) Substitution, 17) Transposition, and 18) Variation. Moreover, Nababan (as cited in Agustino, 2011) adds deletion as a translation technique. He distinguishes the reduction technique and deletion technique. In the reduction technique, the information in the source language is partially omitted in the target language. Meanwhile, in the deletion technique, the translator omits the whole information of the source language; thus its cannot be found in the target language. 


\section{Booster Expression}

Several studies on booster expression have been carried out by experts, especially in the linguistic umbrella. Holmes (1984, p.347) states that '[boosting] involves expressing degrees of commitment or seriousness of intention'. This definition underlines that booster expression is a communication device used to strengthen commitment. Hyland expresses a similar understanding. Hyland (1998b) defines boosters as a communication strategy to increase the strength of a statement and emphasize certainty, strong commitment, belief, and truth. Then Mayer (1997) sees the booster expression as a lexical item used to strengthen confidence in a statement. Peacock (2006) also mentions something similar: a booster is a communication strategy used to reinforce commitment in a statement. Furthermore, Vasileva (2001) explains that a booster is a communication device used to strengthen a commitment to be heard more firmly and clearly. In essence, the five definitions of booster expression expressed above contain the same meaning: booster expression is a strategy that emphasises a statement to achieve the communication goals.

\section{Booster Expression and Rhetorical Devices}

Rhetoric is a communication strategy used by a speaker to convince others to take certain specific actions. Furthermore, he said that rhetoric is not only used to convince and direct action, but rhetoric itself is an action and can be used as a device. Moreover, according to Timothy (2007), rhetorical devices are strategies used by writers or speakers to persuade or even emotionally provoke readers or listeners through certain language styles.

In relation to rhetorical devices, booster expression can be categorized as one. This is because booster expression can be a persuasive device to refer to Aristotele's persuasion modes in conveying argument, divided into four, namely; 1) Logos means using intellectual reasoning and argument structure such as giving claims, sound reasons for them, and supporting evidence. 2) Pathos means influencing the audience or reader feelings to make them take action, believe an argument, or respond in a certain way. 3) Ethos involves persuading the audience or reader that the speaker or writer is credible and well-qualified or possesses other desirable qualities that mean the speaker's arguments carry weight. 4) Kairos means make arguments with the right context and timing. The speaker must ensure that his argument is presented in the right time and context. Related to booster expression as rhetorical devices in a presentation, Jalilifar and Alavi-Nia (2012) provided many functions of booster expression, specifically; 1) Intensifier, 2) Personal Involvement, 3) Boosting Epistemic Commitment, 4) Force Indication, 5) Emphasis Expression, 6) Source tagging, 7) Bounding emphatics, 8) Accentuating ideas, 9) Seeking solidarity, and 10) Rhetorical question.

\section{Methodology}

This study is qualitative research, which is conducted to understand the phenomenon of what the research subject is experiencing, such as behaviour, perception, motivation, action, etc., holistically, and by describing it in the form of words and language (Moleong, 2010 p.6). The data was taken from presentation transcripts provided on the TED.com in this study. The selected data were related to the booster expressions used in presentations. Even though the form of the data were in words or phrases, calculations using numbers were also be carried out further in order to calculate the frequency of use of booster expressions. Furthermore, this study is also included in a descriptive study, in which this study describes the qualitative data. Thus, this study is a qualitative descriptive study, a combination of descriptive and qualitative. This type of qualitative descriptive study is often used to analyse social events, phenomena or circumstances.

In this study, the primary data source was every word and phrase that contained booster expressions in the presentation transcripts provided on TED.com. There was a total of six presentation transcripts were used. The entire presentation transcript deals with the same topic, specifically global warming issues. Then, the secondary data in this study were data collected from previous studies related to this research. This study has two data collection techniques: document analysis (content analysis) and focuses group discussion. In this study, document analysis was carried out by recording expressions that indicate booster expressions in the form of words and phrases and then analysing them based on their functions before it comes to the translation techniques. Then, the Focus Group Discussion (FGD) was carried out by means of group discussions. The aim was to ensure that the expressions that have been collected are included as the data.

There are two triangulations applied to validate the data in this study. They are triangulation of data sources and triangulation of the methods. Triangulation of data sources was carried out in two ways. First, conduct peer-briefing discussions and use a dictionary to obtain information on a word or phrases that indicate a booster expression. Second, using data sources from informants or raters to obtain accurate information. After all, data has been collected. Data analysis is carried out utilizing document analysis. The collected data will be classified based on the theories used in this study, namely the classification of booster expression by Jalilifar and Alavi-Nia (2012) and translation techniques by Molina and Albir (2012). These theories were chosen because these considered the most appropriate theories for analysing the booster expression translation used in presentations. 


\section{Results and Discussion}

The data analysis results show that from 288 collected data, there are 8 types of booster expressions categorised based on their function, which is translated by 6 types of translation techniques. The further discussion is to describe the findings regarding booster expression types and relates them to translation techniques.

\subsection{Types of Booster Expression}

As previously explained, that booster expression is a linguistic device used to strengthen statements (including commitment, truth, and belief) that aim to achieve certain communication goals. There are eight types of booster expression categorised by functions found in the six presentation transcripts on TED.com. The calculations are summarized in the table below.

Table.1 The Types and Frequency of Booster Expression

\begin{tabular}{|c|c|c|}
\hline Types of Booster Expression & Frequency & \% \\
\hline Intensifier & 194 & 67,36 \\
\hline Personal Involvement & 10 & 3,47 \\
\hline Boosting Epistemic Commitment & 24 & 8,33 \\
\hline Force Indication & 10 & 3,47 \\
\hline Source Tagging & 11 & 3,82 \\
\hline Bounding Emphatics & 5 & 1,74 \\
\hline Accentuating Ideas & 23 & 7,99 \\
\hline Seeking Solidarity & 11 & 3,82 \\
\hline TOTAL & $\mathbf{2 8 8}$ & $\mathbf{1 0 0} \%$ \\
\hline
\end{tabular}

The table above explains that the booster expression which functions as an intensifier, is the most commonly found with 194 data or $67,36 \%$ of the total data, while the least is the booster expression with the bounding emphatics functions with only 5 data or $1,74 \%$ from the total data. Furthermore, each booster expression has a rhetorical function. Further explanation will be discussed below.

\section{Intensifier}

An intensifier is a booster expression that intensifies a sentence's elements or strengthens a statement by exaggerating reality. This overexpression of reality describes the seriousness of a situation or problem at hand. The rhetorical purpose of using an intensifier is to lead the audience's thoughts to believe in the truth of the reality revealed by the presenter. The example data of intensifier found in the text, "We have a far greater threat now.".

\section{Personal Involvement}

In its rhetorical function, the use of the personal involvement function aims to show and convince the audience about the presenter's personal commitment to a problem and personal credibility. Similar to intensifier, this function is generally exaggerated, but in this case, something that is conveyed excessively is something that has to do with personal commitment or self-credibility. For example, "Is it fair? Heck, no, that's why I care most about climate change because it is absolutely unfair.

\section{Booster Epistemic Commitment}

This type of booster expression is used to express propositions related to the certainty, possibility, or tendency of a thing. Its rhetorical function is to convince the audience by emphasizing facts. For example," But in reality, that boulder is already at the top of the hill."

\section{Force indication}

Force indication is a tool used by speakers to emphasize the power of the illocution that is conveyed. Some examples of booster expressions as force indications are; I ask you, I tell you, I want you, I beg you, in fact.

\section{Source tagging}

Source tagging is a booster used to strengthen statements by quoting valid facts or data from other sources, increasing audience confidence in the speaker's statement. For example, "Recent scientific reports predict that in the next few decades, earth's fever is on a path to devastation.." 


\section{Bounding emphatics}

Bounding emphatics are a device used to strengthen or re-emphasize existing speech acts, for example; "Moreover, approximately a third of all food produced is not eaten,.."

\section{Accentuating ideas}

Accentuating ideas are booster expressions used to increase the impact and effectiveness of the ideas presented. This type of booster is conveyed by repeatedly conveying ideas so that the audience will unconsciously remember them and following the idea. For example, "But today, I fear it's the industry in which I work that will be judged more harshly because of its impact on the climate -- more harshly than my grandfather's industry, even."

\section{Seeking solidarity}

The seeking solidarity sub-function is a booster used to emphasise illocution's power by assuming that listeners and speakers have the same background knowledge. As an example: "The largest army base in the United States, Fort Hood, is, of course, in Texas."

\subsection{Translation Techniques}

This study found that the translator used six types of translation techniques to translate 288 booster expression data. The types are Established equivalent, Deletion, Reduction, Modulation, Discursive creation, and Linguistic compression. The frequency is summarised in the table below.

Table 2. The Frequency of Translation Techniques

\begin{tabular}{|c|c|c|c|c|c|c|c|}
\hline \multirow{2}{*}{$\begin{array}{l}\text { Types of booster } \\
\text { expressions }\end{array}$} & \multicolumn{6}{|c|}{ Translation Techniques } & \multirow[t]{2}{*}{ TOTAL } \\
\hline & $\begin{array}{l}\text { Established } \\
\text { Equivalent }\end{array}$ & Deletion & Reduction & Modulation & $\begin{array}{l}\text { Discursive } \\
\text { Creation }\end{array}$ & $\begin{array}{l}\text { Linguistics } \\
\text { Compression }\end{array}$ & \\
\hline Intensifier & 130 & 51 & 9 & 1 & 3 & - & 194 \\
\hline Personal Involvement & 4 & 5 & - & 1 & - & - & 10 \\
\hline $\begin{array}{c}\text { Boosting Epistemic } \\
\text { Commitment }\end{array}$ & 20 & 2 & - & 2 & - & - & 24 \\
\hline Bounding Emphatics & 3 & 1 & - & 1 & - & - & 5 \\
\hline Accentuating Ideas & 22 & - & - & - & - & 1 & 23 \\
\hline Seeking Solidarity & 7 & 3 & - & - & - & 1 & 11 \\
\hline TOTAL & 202 & 64 & 10 & 6 & 3 & 3 & 288 \\
\hline
\end{tabular}

From the frequency table of the application of the translation technique above, it is known that the common equivalent technique is the technique most often applied by translators in translating booster expressions with 202 applications. The least frequently applied are discursive creation techniques and linguistic compression with 3 times each.

The translator must choose the translation technique used to translate the data. The following explains each translation technique found to translate the booster expression and the discussion related to the assumptions that underlie the translators in choosing the translation techniques.

\section{Established Equivalent}

The established equivalent technique is a translation technique that uses everyday expressions, expressions or terms that have been commonly used in either the dictionary or the target language as the equivalent of the source language text. The use of equivalent techniques is usually context-bound, not a word-for-word translation. This technique is also known as recognized translation / accepted standard translation or official translation.

This technique is the most common technique, with 202 data from all data. This technique is found mostly in booster expression with intensifier function. Apart from the fact that the frequency intensifier is the most found in the data, most booster types are also often used in the target language, so it is not difficult for the translator to find the equivalent words in the target language. The following is an example of datum related to the use of common equivalent techniques. 
SL : Over the next year or two, I'm super excited to see this go to its first commercial-scale pilots in both the air conditioning and refrigeration space.

ST : Satu atau dua tahun berikutnya, saya sangat gembira karena ini meluncur pada skala komersial pertama kali dalam pasar sistem pendinginan.

The translator applies the eshtablished equivalent technique to maintain the existing booster expression in the above datum. The word "super" in English is translated into the word "sangat" in Indonesian. This is common in Indonesian, although in Indonesian itself there is the word "super" but the translator chooses to use the word "sangat" is considered more appropriate and can form the equivalent meaning of the booster expression. Functionally, there is no shift in translating the booster expression from "super" to "sangat", both of which are still intensifiers.

\section{Deletion Technique}

The second most widely used translation technique in translating booster expressions in this study is the deletion technique. The Deletion technique is a technique in which the translator removes all the information in the source language to no longer be found in the target language. The use of this technique results in not achieving equivalence in translating information from the source language to the target language so that the quality of the translation will be inaccurate.

This study found that the translation applied deletion techniques in 63 data from the total data. Translators quite widely apply this technique. Several reasons may underlie the use of this technique. First, this technique is known to be the most common in the expression booster with intensifier type. There is an assumption that the translator deliberately eliminates this type of booster expression because they think it is not so important to use. The thing that underlies this is the cultural differences in booster expressions in English and Indonesian. English is generally more expressive so that there are many intensifiers found in this language, while Indonesian is less expressive. Thus, the translators do many deletions because they do not find any urgency in using it. The second reason is the lack of translator competence. We know that the booster expression in English is more varied than in Indonesian, especially in formal Indonesian. This can be assumed to be the reason for the translator to omit the booster expression in Indonesian. The translator may not find the equivalent booster expression in Indonesian due to less variation.

Below are some examples of how deletion techniques can be applied to existing data.

SL: Yes, we absolutely do need to recognize what's at stake

ST: Ya, kita perlu mengenali apa yang dipertaruhkan.

The deletion technique in the datum above is shown from the absence of the booster expression "absolutely do" in the target language. In the source language, the use of the booster expression "absolutely does" aims to represent the feeling of the presenter who wants to emphasize to the audience that the information he is conveying is something very important and urgent to do. Meanwhile, the use of deletion techniques in translation in the target language eliminates the sense of booster so that there is no longer any urgency in the information conveyed. However, in the target language, the message conveyed as a whole remains the same and is not affected by removing the translator's booster expression.

\section{Reduction Technique}

In translation, there are similarities between reduction techniques and deletion techniques. The translator removes all the information in the target language in the deletion technique. This is slightly different from the reduction technique, where the translator only removes part of the information. 10 data are translated using reduction techniques from the total data. The reduction technique in this study is entirely found in data that has double booster expressions. The translator has to reduce some of the booster expressions. The closest reason is that the translator finds no urgency in using the double booster expression. The same reason as the deletion technique is because the culture of using the expression booster is different.

The following is an example related to the use of this reduction technique

ST: This includes everything from the air conditioners I so desperately wanted during my summer vacations to the refrigeration systems that keep our food safe and cold for us in our supermarkets to the industrial-scale systems that keep our data centers operational. 
TL: Ini termasuk semuanya dari pendingin ruangan yang saya sangat inginkan pada liburan musim panas saya pada sistem pendingin yang membuat makanan tetap baik dan dingin di supermarket, hingga sistem skala industri yang menjaga agar pusat data tetap bekerja.

Overall, there is no visible part of the message that was removed from the translation in the example datum above. However, if examined more deeply, there is an intensifier that the translator does not translate into the target language. In the source language, a double booster functions as an intensifier, namely "so" and deepened by the word "desperately" which indicates that the speaker, in this case the presenter, is desperate for it than that. However, the translator does not maintain this double intensifier booster into the target language and only uses one intensifier only, it is "sangat".

\section{Modulation Technique}

Modulation technique is a translation technique in which the translator changes the point of view, focus or cognitive aspects that exist in the source language, both in terms of structure and lexical in the target language. Even so, the translation results will still give the same message.

There are 6 data found related to the use of modulation techniques. Viewed from the booster expression data translated by modulation techniques, it can be concluded that the reason the translator applies this technique in this study is to achieve translation acceptability in the target language to achieve a good translation quality. What is meant by acceptability in translation is how the translation can be easily accepted and understood in the target language.

Here is an example of the application of the modulation technique:

SL : And while I tried my very, very best, I was never able to persuade them to get one.

TL : Dan meskipun saya berusaha sebisa mungkin, Saya tidak berhasil membujuk mereka untuk membelinya.

There is a change in focus or point of view from the English translated into Indonesian. There is the phrase "my very, very best" as a marker of booster expression in the source language. There is a "personal sense" existing in the phrase. It can be interpreted according to the context that the presenter has tried the best version of himself. In the target language, "my very, very best" is translated as "sebisa mungkin", here the point of view or focus changes by removing the sense of personal where there is no more emphasis on the presenter's " best version" and more emphasis on the efforts the speaker has done.

\section{Discursive Creation Technique}

Translators commonly use the discursive creation technique to display the temporary equivalence of the source language in the target language, but the translation is out of context. There are 3 data found in translating booster expression in this study. From the three data found in the translation of the presentation transcripts used in this study, it appears that the translator cannot find the right equivalent word to transfer the booster expression in Indonesian so that discursive creations appear.

An example of the discursive creation technique is below.

SL : We did a great job with the Montreal Protocol to limit the production of chlorofluorocarbons, CFCs, because of their effect on the ozone layer

ST : Kita melakukan hal yang benar dengan Protokol Montreal untuk membatasi produksi klorofluorokarbon, CFC, karena pengaruhnya pada lapisan ozon.

In the data example above, the word "great" in the source language is translated into the word "benar" in the target language. The word "great" in English has two meanings; first, the amount or intensity above average and second is the ability or quality above average. When viewed from the whole sentence or according to the context, the word "great" will be more appropriate if it is translated as "luar biasa" or "hebat". Meanwhile, "benar" in KBBI (Indonesian Dictionary) means; 1. As it should be, 2. Being impartial, 3. Righteous (hearted), 4. Trustworthy; do not lie, and 5. Legitimate. Therefore, the translation of "great" to be "benar" is categorised as a creation discursive technique.

\section{Linguistic Compression}

The linguistic compression technique is a technique used by translators to synthesize linguistic elements in the target language to become more concise. This study found 3 data regarding the application of linguistic compression techniques. The translator's 
application of linguistic compression techniques is intended to achieve the acceptability aspect of translation in the target language. Thus, readers in the target language can easily understand the translation message.

Below is an example of data that will be discussed.

SL : And it is, believe me. I'm a scientist, I know.

TL : Memang, percayalah. Saya ilmuwan, saya tahu.

The presenter uses the expression "believe me" as a booster expression with a force indication function to convince the audience about her competence. This expression is then translated in the target language into "percayalah" which has the same meaning. In these data, the translator uses linguistic compression techniques to synthesize the referent word "me" and translate it into a more concise, namely "percayalah" (believe) not "percayalah padaku" (believe me).

\section{Conclusion}

From the six presentation transcripts used as data sources in this study, the conclusion is that there are eight types of booster expressions as rhetorical tools. The eight types of booster expression are Intensifier, Personal involvement, Boosting epistemic commitment, Force indication, Bounding emphatics, Seeking solidarity, Accentuating ideas, Source tagging. Intensifier booster is the type with the most frequency, while bounding emphatic booster is the type with the lowest frequency. The rhetorical function of the booster expression was found to be broadly strengthening the presenter's statements, convincing the audience, and leading the audience's opinions.

There are six types of translation techniques used to translate booster expressions from the six presentation transcripts. The translation techniques are Establish equivalent, Deletion, Reduction, Modulation, Discursive creation, and Linguistic compression. Establish equivalent is the most frequently applied techniques, while Discursive creation and Linguistic compression are the less. Another interesting thing is that translators apply the deletion technique quite often. Several things affect the application of deletion and reduction techniques, specifically cultural differences regarding using different booster expressions between the source language and the target language and the translator's lack of translator competence in finding equivalent words.

This research also underlines that it is important for a translator to have overall competence and fully understand the source language's text. Related to this research, the translators omit a lot of information about booster expressions in the presentation's transcripts that they translated since they did not understand that the booster expressions conveyed by presenters in the presentations could contain rhetorical messages as a communication strategy.

Funding: This research received no external funding

Acknowledgements: I would like to send much appreciation to my supervisors, Prof M.R. Nababan, M.Ed, M.A, Ph.D and Prof Riyadi Santoso, M.Ed, Ph.D, for their support and advice and suggestions.

Conflicts of Interest: The authors declare no conflict of interest.

\section{References}

[1] Hyland, K. (1998). Boosting, hedging, and the negotiation of academic knowledge text, 18(3), 349382.doi:https://doi.org/10.1515/text.1.1998.18.3.349

[2] Ilham, Nababan, M. R., Kristina, D., \& Wiratno, T. (2018). The evolution of booster on the assertive speech act used in two decades version of translation. 4th PRASASTI International Conference on Recent Linguistics Research (PRASASTI 2018). 166, 546-551. Surakarta: Atlantis Press. doi:http://dx.doi.org/10.2991/prasasti-18.2018.100

[3] Jalilifar, A., \& Alavi-Nia, M. (2012, May 25). We are surprised; wasn't iran disgraced there? A functional analysis of hedges and boosters in televised Iranian and American presidential debates. Discourse \& Communication, VI(2), 135 -161. doi:10.1177/1750481311434763

[4] Larson, M.L. (1984). Meaning-Based Translator: A Guide to Cross-Language Equivalence. Lanham: University Press of America, TM Inc

[5] Catford, J.C. (1978). A Linguistic Theory of Translation. Oxford: Oxford University Press

[6] Newmark, P. (1988). A Textbook of Translation. New York: Prentice-Hall International.

[7] Nida, E.A., dan Charles R.T. (1969). Theory and Practice of Translation: Leiden: E.J. Brill.

[8] Molina, L., dan Albir, A.H. (2002). Translation Techniques Revisited: A Dynamic and Functionalist Approach. META Journal, $X L V I I, 4,2002$.

[9] Meyer, P. G. (1997). Hedging strategies in written academic. Dalam M. R, \& S. H, Hedging and discourse: approaches to the analysis of a pragmatic (hal. 21-41). New York: Walter de Gruyter. 
[10] Holmes, J. (1982, December 1). Expressing doubt and certainty in English. RELC Journal, 13(2), 9 - 28. doi:https://doi.org/10.1177\%2F003368828201300202

[11] Vassileva, I. (2001, January ). Commitment and Detachment in English and Bulgarian Academic Writing. English for Specific Purposes, XX(1), 83-102. doi:https://doi.org/10.1016/S0889-4906(99)00029-0

[12] Moleong, L.J. (2010). Metode Penelitian Kualitatif. Bandung: PT Remaja Rosdakarya.

[13] Peacock, M. (2006). A cross-disciplinary comparison of boosting in research articles. Semantic Scholar Journal. 1 (1): $61-84$. doi: 10.3366/cor.2006.1.1.61

[14] Agustino.G. (2011). Analysis of Translation Technique and Translation Quality of Flight Attendant Manual. Thesis. Sebelas Maret University. 